\title{
超ナノ微結晶ダイヤモンド/水素化アモルファスカーボン 混相膜の受光素子への応用
}

\author{
大曲 新矢・吉武 剛 \\ 九州大学大学院総合理工学府量子プロセス理工学専攻 槅816-8580 福岡県春日市春日公園 6-1 \\ （2012 年 6 月 29 日受付；2012 年 8 月 2 日掲載決定）

\section{Application of Ultrananocrystalline Diamond/Hydrogenated Amorphous Carbon Composite Films to Photodetectors}

\author{
Shinya Ohmagari and Tsuyoshi Yoshitake \\ Kyushu University, 6-1 Kasuga-koen, Kasuga, Fukuoka 816-8580
}

(Received June 29, 2012 ; Accepted August 2, 2012)

\begin{abstract}
Ultrananocrystalline diamond/hydrogenated amorphous carbon composite (UNCD/a-C:H) film is a new candidate material applicable to optoelectronic devices owing to its unique electrical and optical properties. This paper describes a recent progress in the research on the application of semiconducting UNCD/a-C:H films to photodetectors. p-Type conduction accompanied by an enhancement in the carrier concentration was realized by boron doping. Spectral response measurement showed obvious photocurrent in the wavelength of shorter than $280 \mathrm{~nm}$ and above $500 \mathrm{~nm}$, which probably originate from UNCD grains and mid-gap states owing to grain boundaries, respectively. Photodiodes comprising p-type UNCD/a-C:H films and n-type Si substrates exhibited a clear response for deep-ultraviolet light, and the external quantum efficiency and responsivity were more than $70 \%$ and $130 \mathrm{~mA} / \mathrm{W}$, respectively. It was experimentally proved that $\mathrm{UNCD} / \mathrm{a}-\mathrm{C}: \mathrm{H}$ is a potential material for the application to photodetectors.
\end{abstract}

KEYWORDS : ultrananocrystalline diamond, optoelectronic devices, photodetectors, semiconducting, UV detectors

\section{1.は じめに}

IV 族元素周期表において Si（シリコン）の一つ上に 位置する C (カーボン) は, $\mathrm{sp}$ から $\mathrm{sp}^{3}$ まで様々な原子 構造を成すことが可能で, 半導体から金属, 絶縁体まで 幅広い電子物性が発現する。電気絶縁性の高いアモルフ アスカーボンと半導体物性が付与可能なダイヤモンドが 混在した, “超ナノ微結晶ダイヤモンド（ultrananocrystalline diamond, UNCD)/水素化アモルファスカーボン (hydrogenated amorphous carbon, a-C:H) 混相 (UNCD/ $\mathrm{a}-\mathrm{C}: \mathrm{H})$ 膜” ${ }^{1)}$ は, 新規ダイヤモンド系ナノカーボン材料 であり，（a）異種基板上への形成が容易，（b）多結晶ダ イヤモンドとは対照的にきわめて滑らかな膜表面を有す る，(c) 膜中に無数の UNCD 結晶の界面・粒界が内在

E-mail : tsuyoshi_yoshitake@kyudai.jp
し，それを起源とすると考えられる大きな光吸収係数が 発現する ${ }^{2)}$ ，(d）同起源と考えられる窒素ドープによる キャリア濃度増加を伴った $\mathrm{n}$ 型化が可能である ${ }^{3)}$, 等の 特徴を有する。

Table 1 に関連材料物質の一つである, ナノ微結晶ダ イヤモンド (nanocrystalline diamond, NCD) 膜 ${ }^{4)} と の$ 物 性比較を示す。NCD 膜の成長には, ダイヤモンドパウ ダーによる核植込みやスクラッチ処理など “シーディン グ処理”が必要不可欠であり, 結晶はシーディング核を 起点とした柱状構造の成長様式をとる。粒径は膜厚に依 存し，100 nm 程度の大きさまで制御が可能である。 $\mathrm{sp}^{3}$ 比率がきわめて高いため, 透過性および熱伝導性も優 れ, その物性は単結晶・多結晶ダイヤモンド薄膜に近 い。それに対して UNCD/a-C:H 膜では, プラズマ中も しくは基板表面で連続的に起こる核生成プロセスで膜が 形成されていく。そのため, 膜面内のみならず膜厚方向 
Table 1. (color online). Comparison between NCD films and UNCD/a-C:H films.

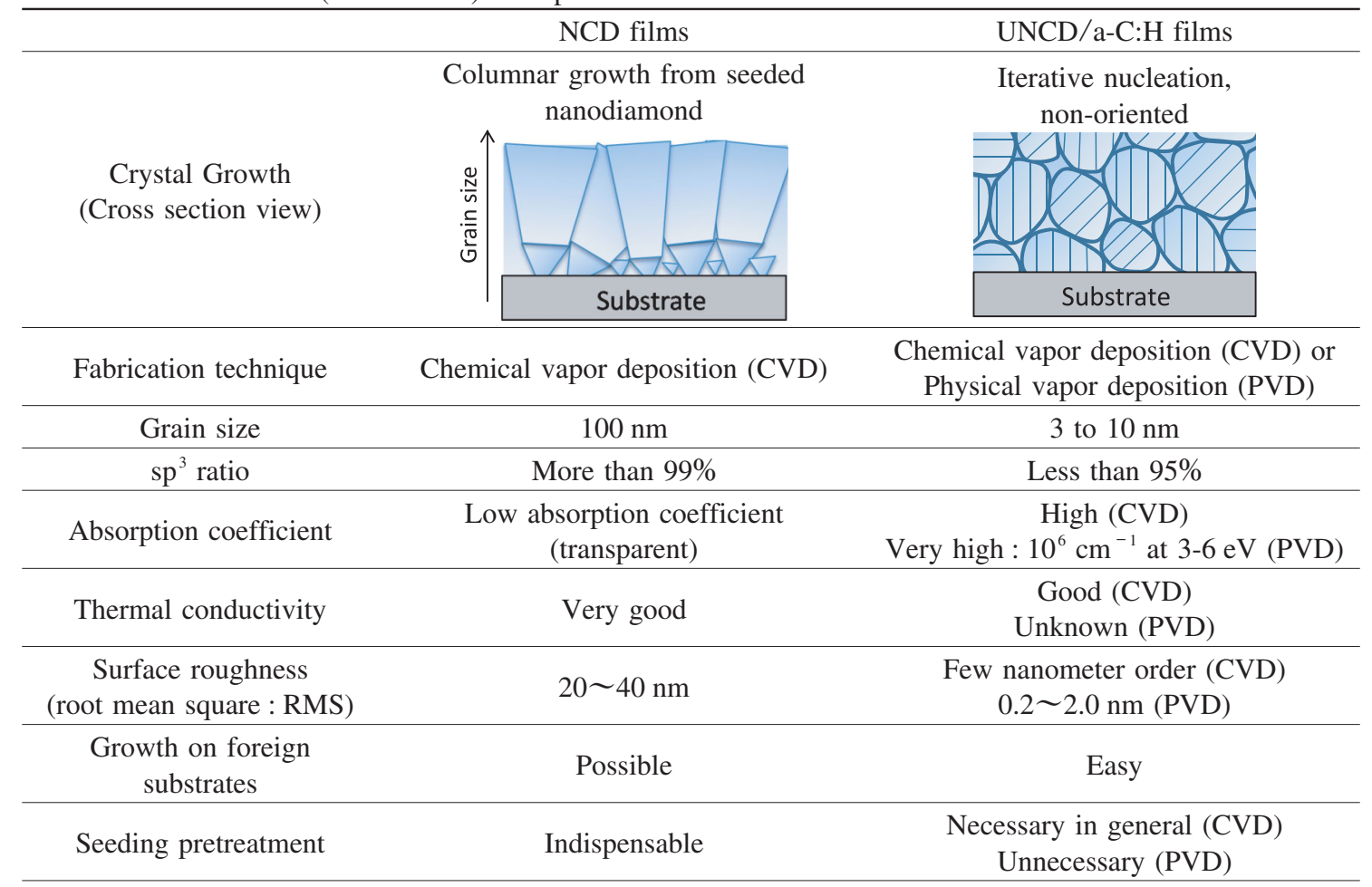

にも無数の UNCD 結晶とそれに伴う多くの結晶粒界が 存在する。分子動力学シミュレーションによると, UNCD 結晶粒界によってダイヤモンドバンドギャップ 間に新たなエネルギー準位, すなわち中間準位が発現 し，また粒界への不純物ドープによってそれらの準位が 拡大することが予測されている5)。UNCD/a-C:H の n 型 化に関しては, ドープされた窒素はダイヤモンド格子内 ではなく結晶粒界中に偏在し, フェルミ準位が伝導帯側 にシフトすることが報告されている5)。UNCD/a-C:H で は, 粒界が膜の光・電気物性に関して重要な役割を担う と考えられる。

通常, ダイヤモンドの気相合成には化学気相成長 (chemical vapor deposition, CVD) 法が用いられ, UNCD/ $\mathrm{a}-\mathrm{C}: \mathrm{H}$ 膜の合成に関しても同様である ${ }^{6,7)}$ 。それに対し て, 我々は物理気相成長 (physical vapor deposition, PVD）法の中でも非平衡性のきわめて強いレーザアブレ ーション（pulsed laser deposition, PLD）法と同軸型アー クプラズマ法で UNCD/a-C:H 膜の成長に成功してい る $^{8,9)}$ 。これらの PVD 法では, 低温 $\left(<550^{\circ} \mathrm{C}\right)$ かつ高 速 $(\sim 80 \mu \mathrm{m} / \mathrm{h})$ の成膜を, シーディング処理無しで可 能である。物性では, CVD 法の膜と比べて光吸収係数 が可視域で 1〜2 桁大きく，また表面の平滑性を表す平 均荒さ (root mean square, RMS) 值が約 1 桁小さくなる ことがわかっている。大きな光吸収係数は受光素子への
応用に有利であり興味深い。

これまでにダイヤモンドのフォノン物性に着目したヒ ートシンク ${ }^{10)}$, SAW デバイス ${ }^{11)}$, NEMS/MEMS ${ }^{12)}$ に関 する研究が活発に行われてきたが, 半導体物性, 特に受 光素子応用に注目した基礎物性探索はされてこなかっ た。我々はこれまでに UNCD/a-C:H 膜の創製および伝 導型制御に取り組み，ホウ素ドープによる $\mathrm{p}$ 型化 ${ }^{13)}$, 窒 素ドープによる $\mathrm{n}$ 型化 ${ }^{14)}$ が再現性良く発現することを明 らかにしてきた。本寄稿では, PLD 法の UNCD/a-C:H 膜に関して行った，ホウ素ドープによる $\mathrm{p}$ 型化と, それ に基づいて試作した $\mathrm{n}$ 型 $\mathrm{Si}$ とのへテロ接合フォトダイ オードの動作例を解説する。

\section{2. 半導体物性制御}

Fig. 1 に PLD 法で作製した UNCD/a-C:H 膜の X 線回 折パターンを示す。測定はデバイ-シェラー光学系で行 い,イメージングプレートで回折像を記録した。 diamond-111に起因する明確な回折像および XRD パ夕 ーンが得られており，膜中に UNCD 結晶が成長してい ることが確認できる。シェラーの式から見積もった平均 粒径は約 $5 \mathrm{~nm}$ であった。ホウ素ドープした試料では結 晶粒成長促進の効果が認められ, 粒径が $5 \mathrm{~nm}$ から 23 $\mathrm{nm}$ まで上昇した ${ }^{15)}$ 。ダイヤモンド膜の気相成長は, 成 長過程で一時的に形成される欠陥を起点に促進されるこ 


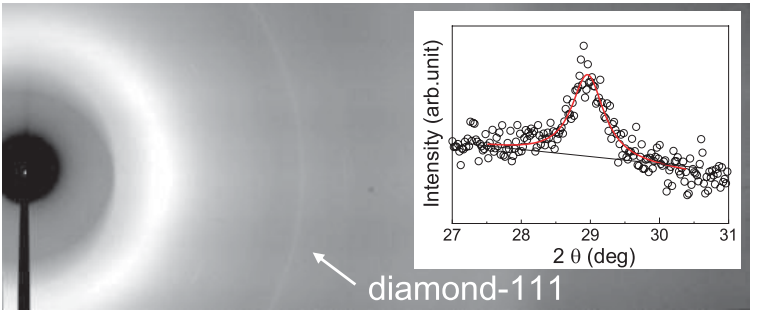

Fig. 1. (color online). Debye-Scherrer rings of undoped $\mathrm{UNCD} / \mathrm{a}-\mathrm{C}: \mathrm{H}$ films obtained by imaging plate. The inset shows the typical XRD pattern.

と，またその欠陥形成には成長表面のフェルミエネルギ 一のシフトが大きく影響することが過去に理論予測され ている ${ }^{16)}$ 。 $\mathrm{p}$ 型ドーパントであるホウ素原子の添加によ り一時的な欠陥形成が容易になり，UNCD 結晶の成長 が助長されたことが考えられる。

ホウ素ドープ UNCD/a-C:H 膜の電気伝導度温度依存 性（ $\sigma$-T プロット）を Fig. 2 に示す。ドープ量により伝 導度が大幅に上昇し, また熱起電力法で $\mathrm{p}$ 型伝導化を確 認した ${ }^{13)}$ 。 $\sigma$-T プロットの傾きから見積もられる活性化 エネルギーは約 100〜200 meVであり，その值はホウ素 原子がダイヤモンド格子内の置換原子位置にドープされ た場合のアクセプタ準位 $(370 \mathrm{meV})$ と価電子带上端と のエネルギー差より小さい。単結晶・多結晶ダイヤモン ドに扔けるキャリア発現機構とは異なると考えられる。 電気伝導度の対数と $\mathrm{T}^{-1 / m}$ の温度依存性をプロットした ところ, $m=4$ の 3 次元ホッピングでなく, $m=2$ の 1 次 元キャリア伝導 ${ }^{17}$ が優勢であることがわかった。このこ とはキャリア伝導が，伝導路が空間的に制限された $\mathrm{UNCD}$ 結晶間の粒界で生じていることを示唆している。 Fig. 3 に, 室温におけるキャリア密度および電気伝導度 のホウ素ドープ量依存性を示す。キャリア密度は約 $10^{15}$ $\mathrm{cm}^{-3} \sim 10^{17} \mathrm{~cm}^{-3}$ 範囲で幅広く制御可能であることがわ かる。これは, 不純物添加でほとんど電気伝導度は上昇 しない a-C:H 単相膜の場合と，大きく異なる。

キャリア密度上昇の起源を探るために, 膜中での化学 結合状態を吸収端近傍 X 線吸収微細構造（NEXAFS） 解析で評価した。結果を Fig. 4 に示す。スペクトルは error-function をステップ関数で差し引いた後, Gaussian ピークでフィッティングを行った。まずアンドーブ膜と

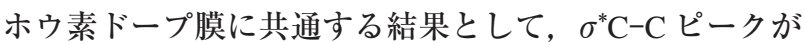
$\sigma^{*} \mathrm{C}-\mathrm{H}$ および $\pi^{*} \mathrm{C} \equiv \mathrm{C}$ と比べて大きくなることが挙げら れる。 $\sigma^{*} \mathrm{C}-\mathrm{C}$ ピークはダイヤモンド結晶の基本格子を示 しており，膜中の UNCD 粒に起因していると考えられ る。ホウ素ドープ膜に関しては，このピークが高エネル ギー側にシフトし，ピーク強度の増大がみられた。

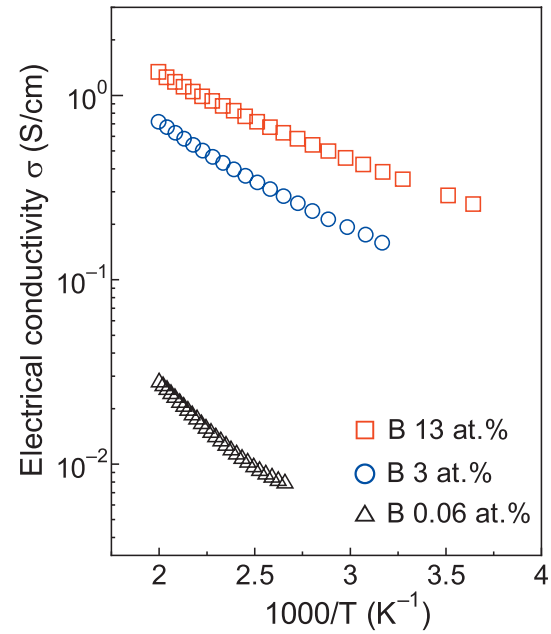

Fig. 2. (color online). Temperature dependence of electrical conductivity of boron-incorporated UNCD/a-C:H films.

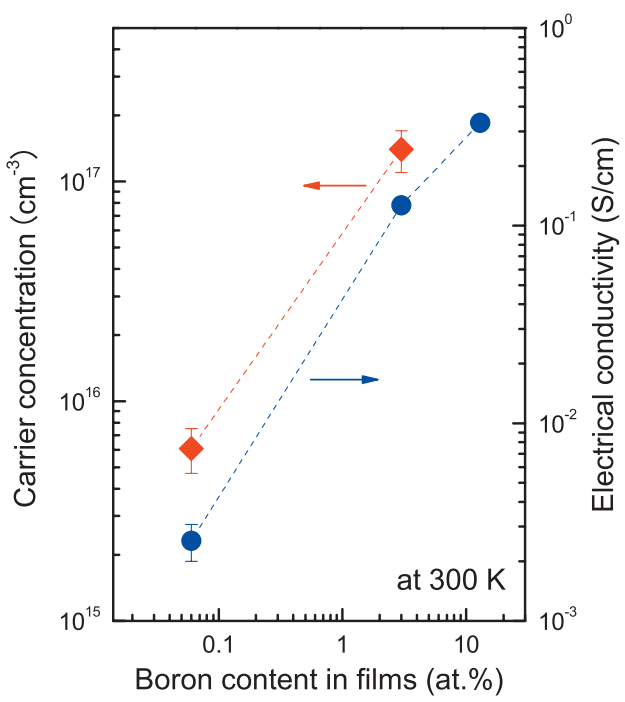

Fig. 3. (color online). Carrier concentration and electrical conductivity estimated at room temperature as a function of amount of doped boron.

NEXAFS は結合距離の情報にきわめて敏感な測定法で あり，ホウ素ドープによる結晶粒上昇と格子定数の僅か な変化を反映しているものと思われる。3 試料間を比較 すると，ドープ量上昇に伴い $\sigma^{*} \mathrm{C}-\mathrm{H}$ ピークが減少し, $\sigma^{*} \mathrm{C}-\mathrm{B}$ ピークが出現および増大することがわかった。 $\sigma^{*}$ $\mathrm{C}-\mathrm{H}$ は主にダイヤモンド結晶表面を終端する水素基で あり，ドーピングによってこの結合の一部がホウ素原子 によって置換されると考えられる。この考察は，フーリ 工変換赤外分光法 (Fourier transform infrared spectroscopy, FTIR）測定で得られた結果の考察と首尾一 貫する ${ }^{13)}$ 。ドープされたホウ素原子は結晶表面および粒 界中に偏在し， $\mathrm{p}$ 型伝導とキャリア密度上昇に寄与して 


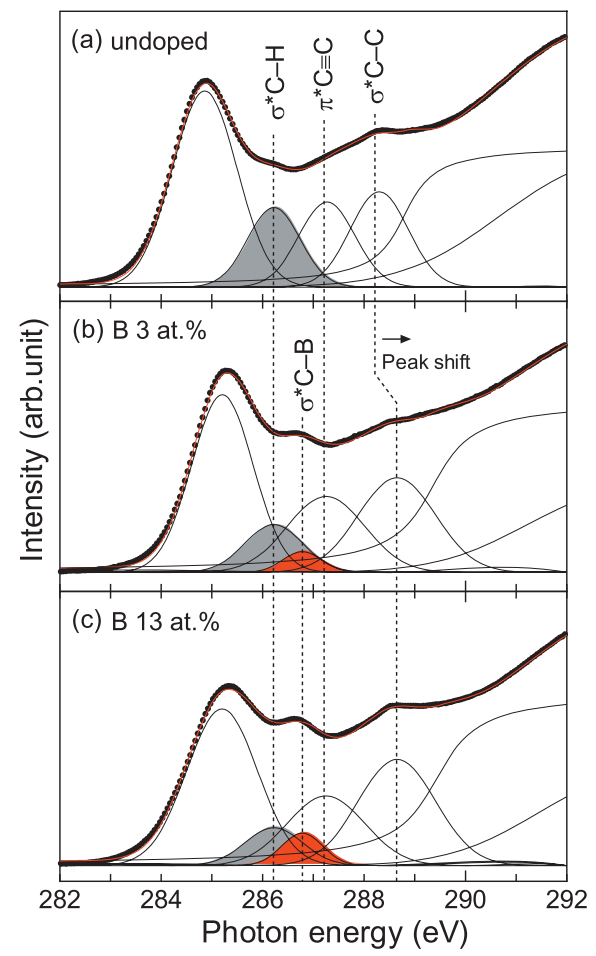

Fig. 4. (color online). NEXAFS C1s spectra of (a) undoped, (b) 3 at.\% boron-incorporated, and (c) 13 at.\% boronincorporated UNCD/a-C:H films.

いると考えられる。詳細なメカニズムはよくわかってい ないが, 粒界の微細構造変化に伴う中間準位の状態変化 が影響していると思われる。

\section{3. 光 学 特 性}

反射スペクトルと透過スペクトルにより算出したホウ 素ドープ UNCD/a-C:H 膜の光吸収スペクトルを Fig. 5 に示す。光吸収係数は光子エネルギー約 $1 \mathrm{eV}$ から立ち 上がり, $3 \sim 6 \mathrm{eV}$ において $10^{5} \mathrm{~cm}^{-1}$ 以上の大きな值を示 す。これは結晶ダイヤモンドの光吸収係数より少なくと も3桁大きい值である。 $(\alpha \mathrm{h} \nu)^{1 / 2}$ プロットから間接バン ドギャップ $1.0 \mathrm{eV}$ と $5.5 \mathrm{eV}$ が見積もられる。a-C:H の 光学バンドギャップは $\mathrm{sp}^{3}$ 比率により $0 \sim 5.0 \mathrm{eV}$ まで変 化することを考虑すると, 前者 $1.0 \mathrm{eV}$ の間接バンドギ ヤップは膜中の $\mathrm{a}-\mathrm{C}: \mathrm{H}$ マトリックスによる $\pi-\pi^{*}$ 遷移に 起因すると考えられる。後者 $5.5 \mathrm{eV}$ の間接遷移は, ダ イヤモンドのバンドギャップと一致しており, 膜中に存 在する UNCD 結晶による光吸収と考えられる。 $(\alpha \mathrm{h} \nu)^{2}$ プロットからは, 直接遷移バンドギャップ約 $3 \mathrm{eV}$ の吸 収端が観測された。これは UNCD/a-C:H に特有であり, 膜中に無数に存在する粒界に起因していると考えられ る。バンド理論計算の結果と照らし合わせると, フェル ミ準位付近にあるダングリングボンドによる欠陥準位か

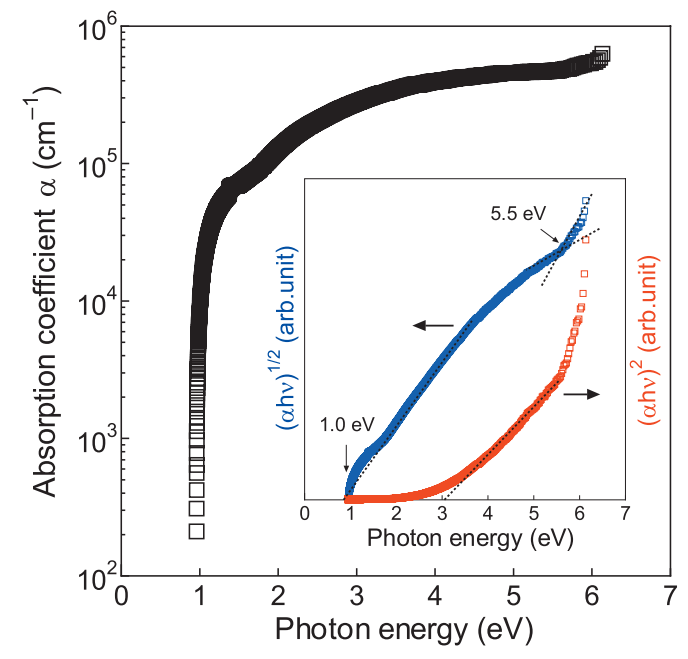

Fig. 5. (color online). Optical absorption $(\alpha)$ spectrum of 3 at.\% boron-incorporated UNCD/a-C:H films. The inset shows the plots in the ordinate axes of $(\alpha \mathrm{h} \nu)^{1 / 2}$ and $(\alpha \mathrm{h} \nu)^{2}$.

ら $\sigma^{*}$ 準位への遷移に対応すると考えられる。a-C:H お よび結晶粒界による光学バンドギャップは太陽電池吸収 層として, UNCD 結晶による間接遷移は紫外線デイテ クター応用として有望である。

光起電力素子としての振る舞いを調べるためには, MSM（金属-半導体-金属）接触，ショットキー接合， pn ホモ接合等の単一材料による評価が適しているが, $\mathrm{UNCD} / \mathrm{a}-\mathrm{C}: \mathrm{H}$ 膜に関してこれらデバイス構造は未だ害 現されていない。我々は紫外域でほとんど感度を持たな いSi を用いたへテロ接合フォトダイオードを形成する ことで, UNCD/a-C:H 膜の受光特性を評価した。この 構造では, 主に UNCD 結晶粒による紫外線受光特性の 評価が可能となる。横型および縦型の電極構造で評価し たヘテロ接合フォトダイオードの分光感度スペクトルを Fig. 6 に示す。フォトレスポンススペクトルは三つの波 長領域において特徴的な振る舞いを示した。まず両デバ イス構造において波長 $280 \mathrm{~nm}$ から短波長側へ向けて大 きな光電流が観測された（領域 1)。前述の光学バンド ギャップの結果を考慮すると, UNCD 結晶粒による紫 外線受光が生じていると考えられる。単結晶ダイヤモン ドではこの波長域の光電流のみを示し, 可視光に対して 高い選択性を持つソーラーブラインドの樑紫外線センサ 一として応用されている ${ }^{18)}$ 。領域 2 において, 光導電型 である横型構造は光電流の変化がほとんど認められない のに対して, 縦型の電極構造では緩やかな立ち上がりが 観測されている。これは基板の影響を反映しており， Si の光電流が観測されていると考えられる。特筆すべき点 は, 領域 3 において特異な立ち上がりが両スペクトルで 

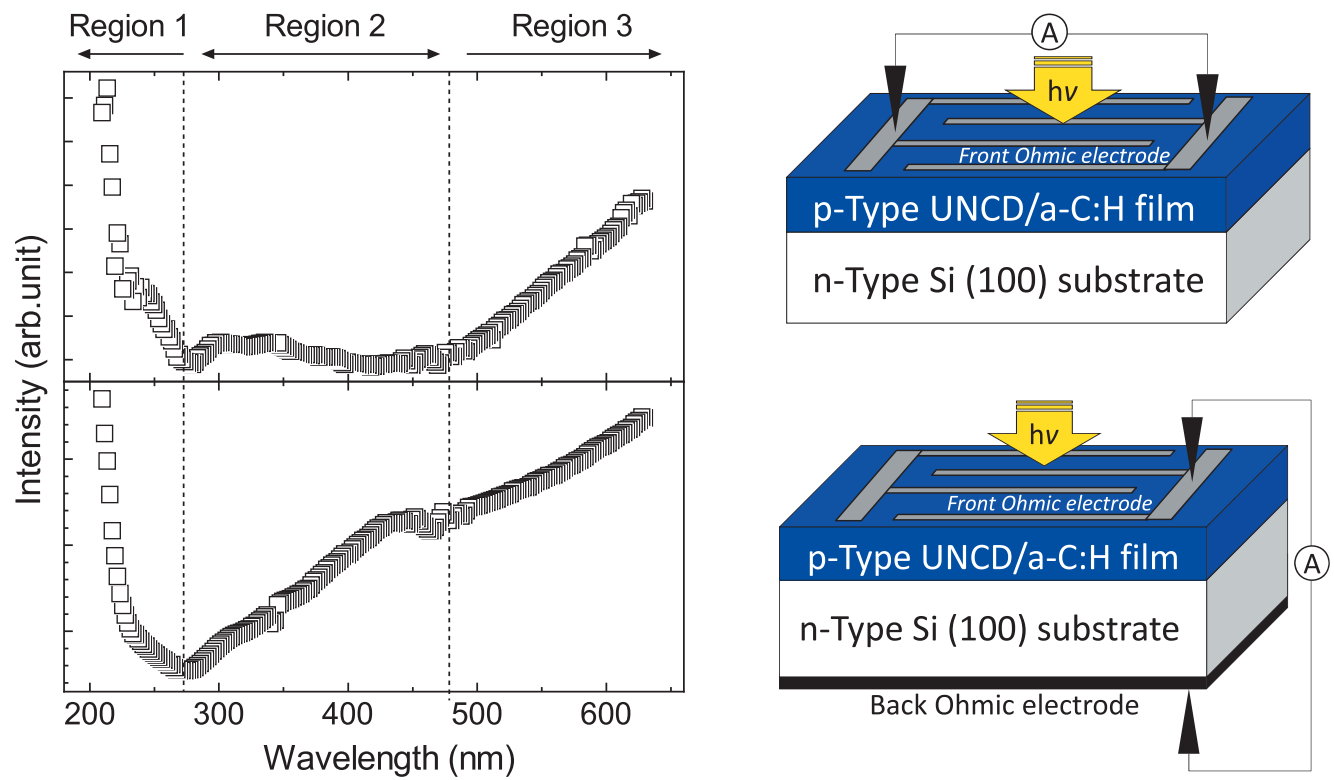

Fig. 6. (color online). Spectral responses of heterojunction diodes comprised of n-type Si substrates and p-type UNCD/a-C:H films in the wavelength between 630 and $210 \mathrm{~nm}$. The measurements were conducted in lateral and vertical diode configurations as shown in the right schematics.

観測されていることである。Si の光吸収のみでは説明 することができず，UNCD 膜の粒界もしくは a-C:H に よる光吸収が関連していると思われる。

\section{4. 深紫外線受光特性}

縦型へテロ接合において，深紫外線受光特性を評価し た。このフォトダイオードの明暗状態における電流電圧 特性を Fig. 7 に示す。暗条件下においては整流比 $10^{2}$ 以 上（ $\pm 1 \mathrm{~V}$ 間）の典型的な整流特性が確認された。ボロ ンドープ層が $\mathrm{p}$ 型半導体膜として動作していることがわ かる。順方向電流で解析した理想因子 $(n)$ は, 低電圧 印加域で $n=1$ の拡散電流, $0.1 \sim 0.5 \mathrm{~V}$ 域で $n=2.8$ の卜 ンネル伝導が付随した再結合電流， $0.7 \mathrm{~V}$ 以上で $n=5.6$ のトンネル電流が支配的となる電流伝導機構となること がわかった ${ }^{19)}$ 。UNCD/a-C:H に特徴的な粒界がトンネル 電流中心として働き，キャリア伝導機構を支配している と考えられる。 $254 \mathrm{~nm}$ の波長を持つ紫外光照射下にお いては，逆バイアス時の電流值が大きく増加しており， 光電流を確認した ${ }^{20)}$ 。 $\mathrm{Si}$ 基板側で生成される紫外フォト キャリアは過剩励起状態となり熱緩和過程を経て消滅し 光電流に寄与しないため, ここで得られた光電流は $\mathrm{UNCD} / \mathrm{a}-\mathrm{C}: \mathrm{H}$ 膜の空乏層で生成されたフォトキャリア に起因するものと考えられる。Fig. 7 の挿入図に，見積 もられた外部量子効率 (external quantum efficiency, $\mathrm{EQE} ）$ と応答電流の逆方向電圧依存性を示す。逆方向電 圧 $5 \mathrm{~V}$ 印加時で外部量子効率，応答電流はそれぞれ

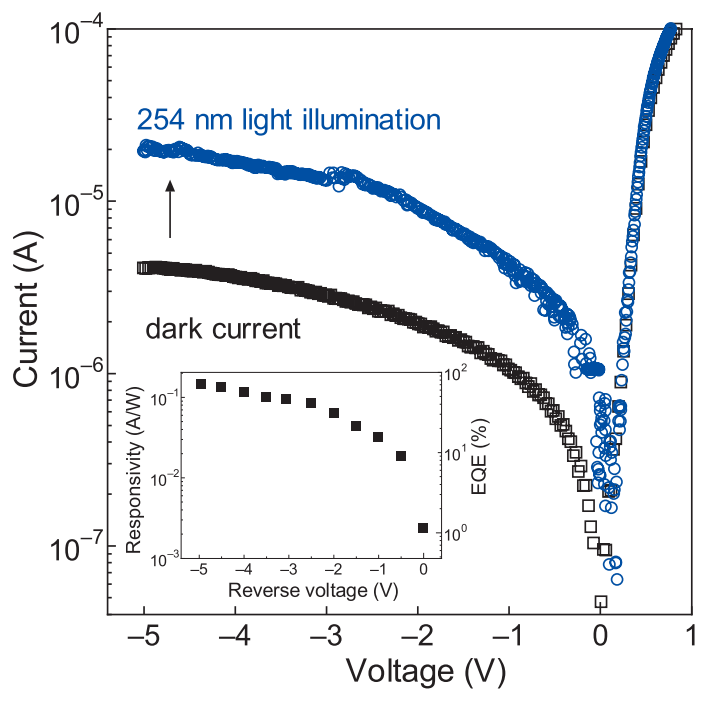

Fig. 7. (color online). Current-voltage characteristics of heterojunction photodiodes evaluated in the dark and under illumination with a $254 \mathrm{~nm}$ monochromatic lamp. The inset shows the reverse voltage dependence of the responsivity and external quantum efficiency.

$71 \%, 0.13 \mathrm{~A} / \mathrm{W}$ といずれも市販の $\mathrm{SiC}, \mathrm{GaN}$ 紫外線セ ンサーを上回る特性が得られた。

Fig. 8 に機械式光チョッパー法で評価した時間応答特 性を示す。照射光の波長㧍よびパワー密度はそれぞれ $200 \mathrm{~nm}, 11.8 \mu \mathrm{W} / \mathrm{cm}^{2}$ である。光照射開始および切断時 の遷移過程における遅延要素は認められず, 高速応答が 


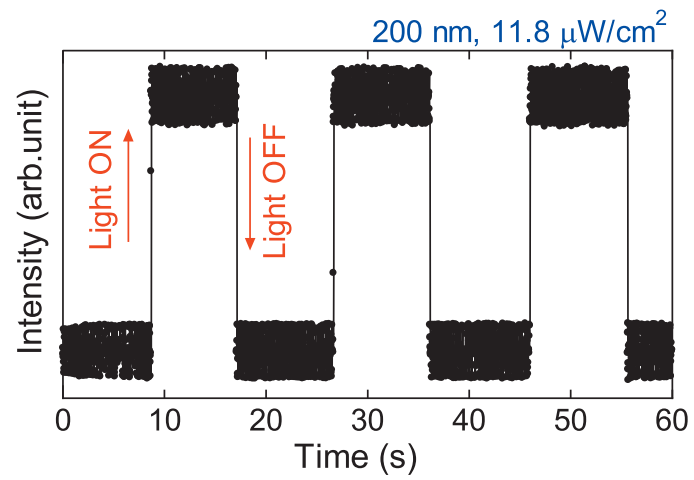

Fig. 8. (color online). Transient behavior of photodiodes to mechanically chopped $200 \mathrm{~nm}$ light with a light intensity of $11.8 \mu \mathrm{w} / \mathrm{cm}^{2}$.

確認された。また, 波長 $193 \mathrm{~nm}$ の ArF エキシマレーザ 光照射に対する追随特性も同様に評価したところ, レー ザパルスの半值全幅とほぼ一致するレスポンスが得られ た。これら優れた紫外受光特性には, UNCD 結晶が紫 外吸収部として働き, 生成されたフォトキャリアは粒界 でトラップされることなく伝導していく特徵的な構造が キーとなっていると我々は考えている。

\section{5. ま め}

超ナノ微結晶ダイヤモンド/水素化アモルファスカー ボン混相（UNCD/a-C:H）膜の構造および化学結合状態 を概説し, 半導体物性制御に基づいて試作した受光素子 の動作を解説した。ホウ素ドープによる $\mathrm{p}$ 型化とキャリ ア濃度が再現性良くコントロール可能であることを明ら かとし，へテロ接合フォトダイオードの試作および評価 を行った。光学特性では UNCD 結晶粒, 粒界にそれぞ れ起因すると考えられる紫外域, 可視域でのフォトキャ リアの生成が観測された。前者は紫外線センサー, 後者 は太陽電池可視光吸収層への応用が期待できる。デバイ ス動作例として, 紫外光照射下におけるフォトダイオー ドの受光特性を評価したところ，70\%を超える高い外 部量子効率が得られた。UNCD/a-C:H がダイヤモンド とも $\mathrm{a}-\mathrm{C}: \mathrm{H}$ とも異なった特徴的な光・電子物性を有する ことを明らかにした。アモルファス系の新しいオプトエ
レクトロニクス材料として今後の展開が期待される。

本研究の成果の一部は, ナノテクノロジー拠点ネット ワーク事業（九州シンクロトロン光研究センター： 090423N，090662N), 文部科学省先端研究施設共用促進 事業（九州シンクロトロン光研究センター：100320AS and 1104035AS), 科学技術振興機構先端的低炭素化技術 開発（ALCA），およびマツダ財団の支援を受けた。

\section{文献}

1) “Ultrananocrystalline Diamond”, ed. by O.A. Schenderova and D.M. Gruen (William Andrew Publishing, Norwich, New York, U.S.A., 2006).

2) T. Yoshitake et al. : Jpn. J. Appl. Phys. 46, L936 (2007).

3) S. Bhattacharyya et al. : Appl. Phys. Lett. 79, 1441 (2001).

4) O.A. Williams et al. : Diamond Relat. Mater. 17, 1080 (2008).

5) P. Zapol et al. : Phys. Rev. B 65, 045403 (2001).

6) K. Tsugawa et al. : Diamond Relat. Matter. 20, 833 (2011).

7) C. Popov et al. : Diamond Relat. Mater. 13, 1371 (2004).

8) T. Yoshitake et al. : Jpn. J. Appl. Phys. 48, 020222 (2009).

9) T. Yoshitake et al. : Jpn. J. Appl. Phys. 49, 015503 (2010).

10) T.H. Kim et al. : Adv. Mater. 20, 2171 (2008).

11) Y.C. Lee et al. : Diamond Relat. Mater. 17, 446 (2008).

12) A.R. Kraussa et al. : Diamond Relat. Mater. 10, 1952 (2001).

13) S. Ohmagari et al. : Jpn. J. Appl. Phys. 49, 031302 (2010).

14) S. Al-Riyami et al. : Appl. Phys. Express 3, 115102 (2010).

15) S. Ohmagari et al. : Jpn. J. Appl. Phys. 51, 025503 (2011).

16) Y. Bar-Yam et al. : Nature 342, 786 (1989).

17) T.B. Tran et al. : Phys. Rev. Lett. 95, 076806 (2005).

18) Y. Koide et al. : Diamond Relat. Mater. 15, 1962 (2006).

19) S. Ohmagari et al. : Jpn. J. Appl. Phys. 50, 035101 (2011).

20) S. Ohmagari et al. : Appl. Phys. Express 5, 065202 (2012). 